\title{
Development and Validation of Educational Neglect and Abuse Questionnaire (Student Form)
}

\author{
Tahere Noeparvar Qarebagh $^{1}$, Ali Zeinali ${ }^{* 2}$ \\ 1. M.A. in Clinical Psychology, Urmia Branch, Islamic Azad University, Urmia, Iran \\ 2. Associate Professor, Department of Psychology, Urmia Branch, Islamic Azad University, Urmia, Iran
}

Accepted: May 13, 2018

\begin{abstract}
Background and Purpose: Educational abuse and neglect are newly presented constructs in scientific texts, and the lack of a standardized instrument to measure them has led to problems in the study of this field of psychology. The present study aimed to develop and validate the educational neglect and abuse questionnaire (student form).

Method: This research is a descriptive study. The statistical population of this study included all the $4^{\text {th }}$ to $6^{\text {th }}$ grade elementary students of Urmia city in the academic year of 2016-2017. A sample of 386 students were selected through random cluster sampling and responded to a questionnaire designed for abuse and neglect.

Results: Results from validating the questionnaire through exploratory factor analysis confirmed the educational neglect and abuse factors. Also the exploratory factor analysis confirmed the values of factor loadings and fitness indices. Using Cronbach's alpha, the reliabilities of the educational abuse and educational neglect were calculated 0.91 and 0.92 , respectively, which are considered as to be very desirable and acceptable

Conclusion: According to the results of this study and the importance of evaluating educational abuse and neglect, especially in elementary students, it can be concluded that the designed questionnaire in this study is a suitable and valid tool for evaluating this area in elementary school students.
\end{abstract}

Keywords: Educational abuse, educational neglect, validity, reliability

Citation: Noeparvar Qarebagh T, Zeinali A. Development and validation of educational neglect and abuse questionnaire (student form). Quarterly Journal of Child Mental Health. 2019; 6(1): 211-222.

*Corresponding author: Ali Zeinali, Associate Professor, Department of Psychology, Urmia Branch, Islamic Azad University, Urmia, Iran. 


\title{
ساخت و بررسى روايى يرسشنامه سوءرفتار و غفلت آموزشى (فرم دانش آموز)
}

\author{
طاهره نوع برورقره باغ '، على زينالى \\ ا. كارشناس ارشد روانشناسى بالينى، واحد اروميه، دانشگاه آزاد اسلامى، اروميه، ايران

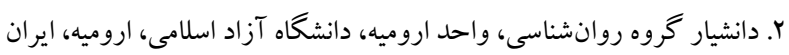

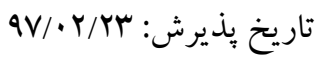

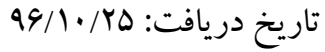

جكيله

زمينه و هدف: سـو فرفتار و غفلت آموزشى، سـازههاى مطرح شـده جديد در متون علمى هستند كه نبود ابزار معتبر براى اندازهگيرى

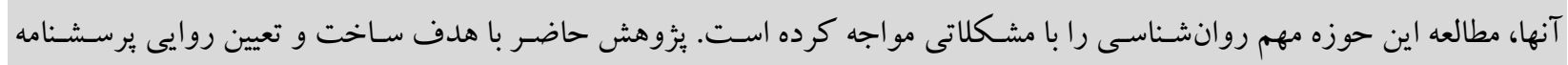

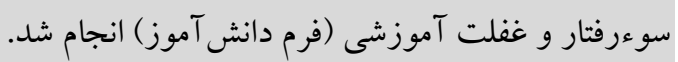

روش: اين بثزوهش، توصيفى است كه جامعه آمارى آن شامل تمامى دانش آموزان بايههاى جهارم تا ششم ابتدايى شهر اروميه در سال

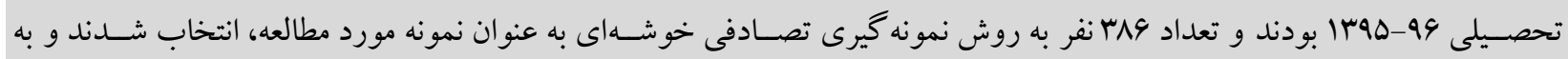

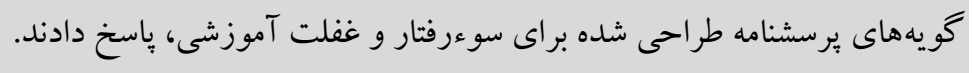

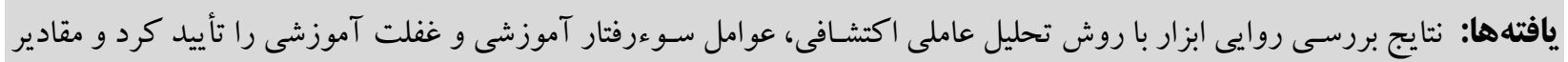

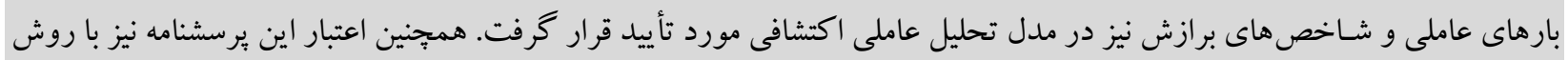

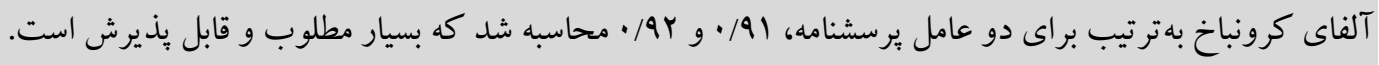

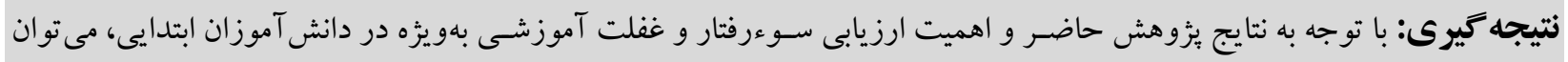

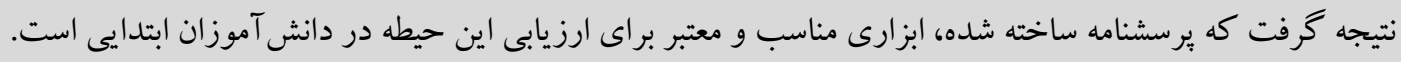
كليدوازهها: سوءرفتار آموزشى، غفلت آموزشى، روايى، اعتبار

*نويسنده مسئول: على زينالى، دانشيار گروه روانشناسى، واحد اروميه، دانشكاه آزاد اسلامى، اروميه، ايران. 


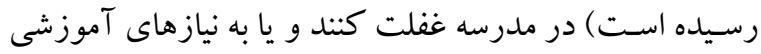

مقدمه

خاص كودكك توجهى نشود (9). به مانند سوءرفتار آموزشى،

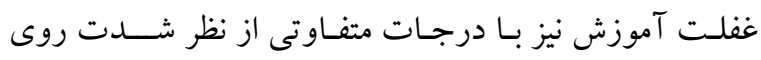
مىدهد ( · او 1). غفلت آموزشى بهمعناى كوتاهى در فراهم كردن امكانات، توجه و نظارتى است كه براى تضمين تعليم و تربيت كودكك ضـرورى اسـت و از جمله مصاديق آن مى توان بـه عدم ثبت نام كود كك در مدرسسـه، اجازه دادن به غيبتهاى

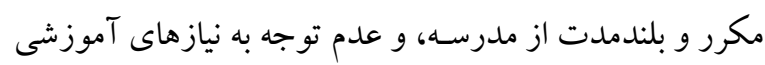

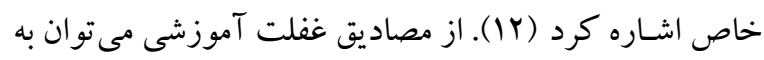
كو تـاهى در ثبـتنـام، فرار مـداوم از مدرســه، و بى توجهى به نيازهاى آموزشسى كودك اشـاره كرد (سا). آجاكك، آدن و بيسونگك، غفلت آموزشى را شامل گريز از مدرسه بهصورت

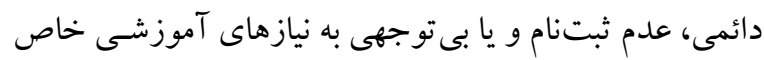

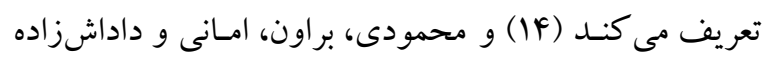

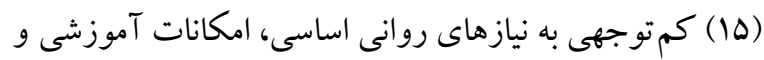

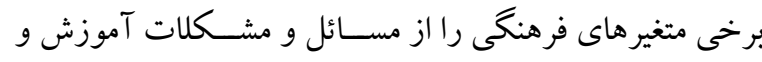
يرورش مى دانند.

مطالعات نشان مىدهند كود كانى كه دجار غفلت آموزشى شدهاند بيشتر احتمال دارد كه نياز به كلاسهاى تقويتى داشته و

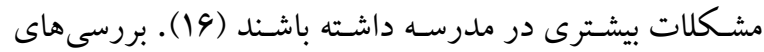
شيوع شناسى در اين زمينه، عيار سوءرفتار و غفلت آموزشى را بالا گزارش كردند. مؤسسسـهـاى حمايت از كود كك در هلند،

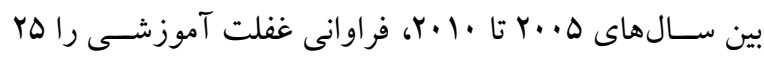

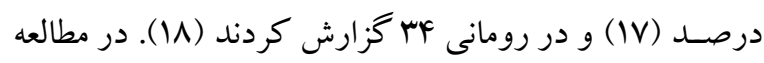

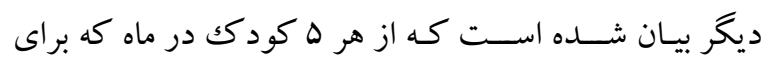

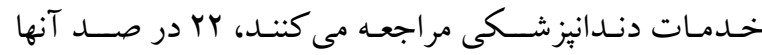

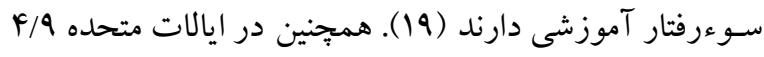

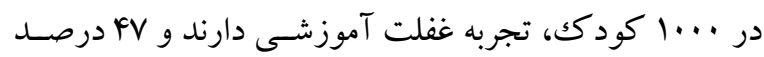
كود كان با تشـخيص سـوءرفتار، تجربه غفلت آموزشسى دارند

4. Sexual Abuse

5. Emotional Abuse

6. Neglect

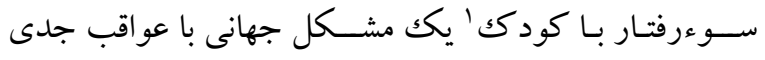
مادامالعمر اسـت كه موجب درد و رنج كود كان و خانوادهها شـده و مى تواند عو اقب طولانىمدت به دنبال داشـته باشد (1).

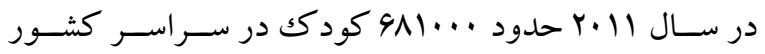
آمريكا، قربانى غفلت و سوءرفتار بودهاند كه درصد بسيارى از

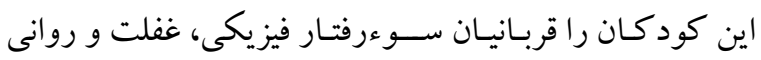

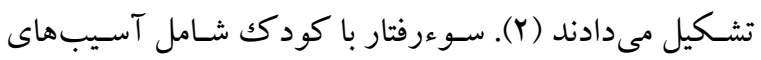

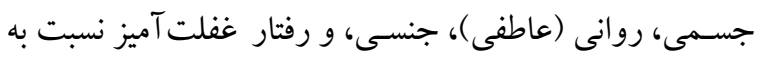

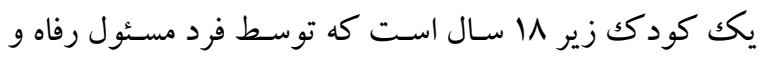
آسايش كود كك اعمال مىشود (r). در وير ايش ينجم راهنماى

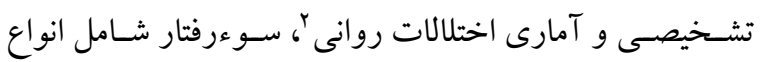

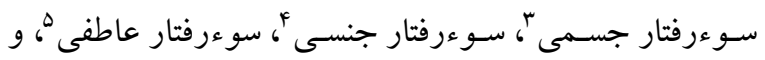

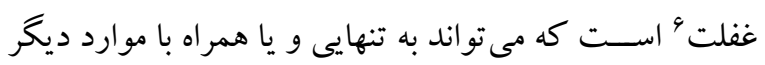
اتفاق بيفتد (r) و در اين راستا ديوب و مككجيبونى سوءر فتار با كود كك را به ينج طبقه شـامل سـوءرفتار جسـمى، سـوءرفتار جنسى، سوءرفتار عاطفى، سوءرفتار آموزشى، و غفلت تقسيم كردند (f) مطالعات بسيارى درباره انواع سوءرفتار با كودك صورت

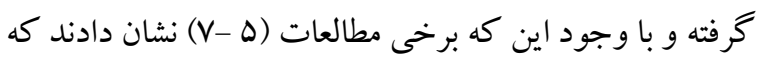
سـو رفتار جسـمى و جنسى مى تواند تبعات آموزشسى داشـته

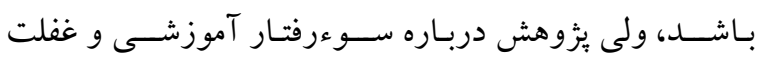
آموزشى در مر احل آغازين است. سوءرفتار آموزشى به معناى درون كو تاهى شـخصى كه مسـئول مر اقبت، حضانت، و كنترل امور كودكك است در جهت فراهم كردن آموزش و يرورش مناسب

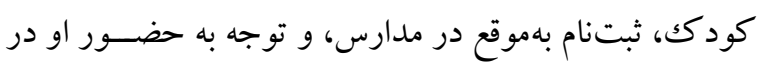

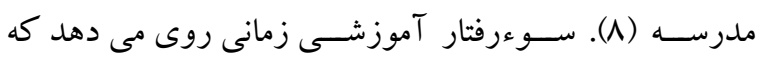

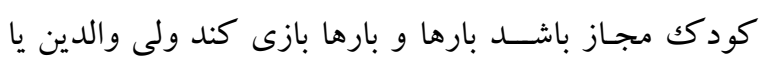

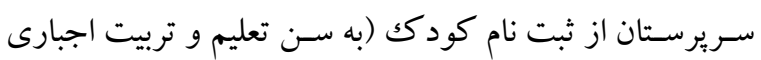

1. Child Abuse

2 . Diagnostic and Statistical Manual of Mental DisordersV: DSM-5

3. Physical Abuse 
دو سازه بهطور مختصر اشاره شده، اما ابزارى براى اندازهگيرى

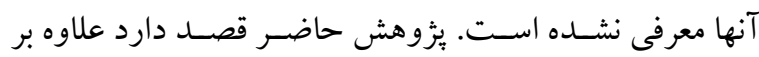

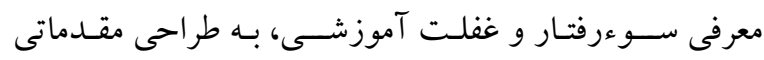

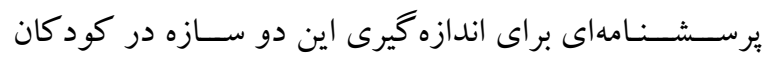
دبستانى ببردازد تا هم خلاء فقدان ابزار هر خند مقدماتى در اين حوزه برطرف شـود و هم با اندازه گيرى اين دو سـازه، شـاهد

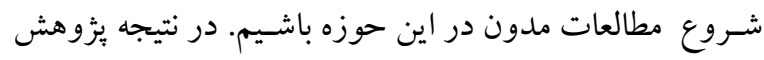

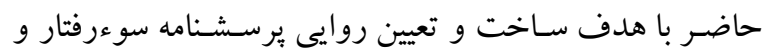
غفلت آموزشى (فرم دانش آموز) انجام شد.

روش

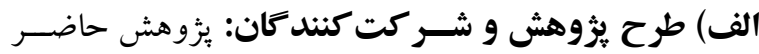
توصيفى است كه با هدف ساخت ابزار انجام شده است. جامعه

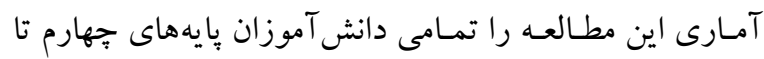
شـشم ابتدايى شهر اروميه در سال تحصيلى 99-هوبها تشكيل مى دادند كه تعداد كل آنها r دختر) بود. حجم نمونـه بر اســاس جـدول موركـان سمب نفر بر آورد شــــ كه با توجه به ريزش هاى احتمالى و بر ایى اطمينان

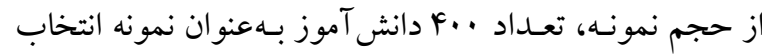

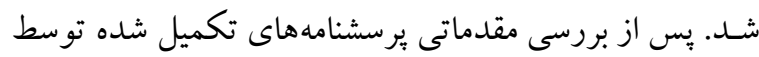

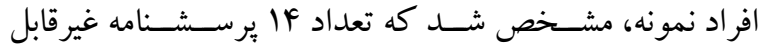

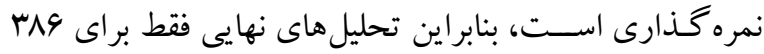

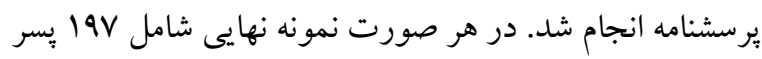

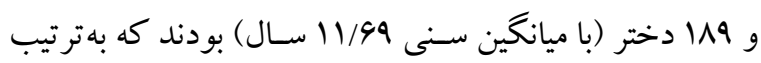

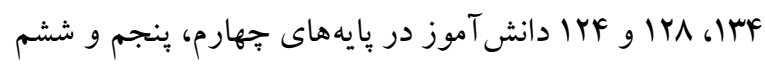

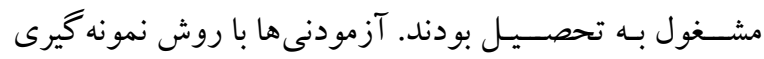
تصـادفى خوشـهاى انتخاب شـدند و معيارهاى ورود به مطالعه شامل: داشتن سن ·· تا سا سال، تحصيل در يايههاى جهارم تا ششم، و برخوردارى از سلامت جسمانى؛ و معيارهاى خروج از

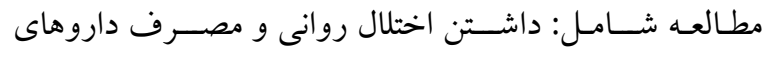
روانيزشكى، وقوع رخدادهاى تنش آور مانند مرگك، طلاق و ...

2. Fourth National Incidence Study of Child Abuse and Neglect
(1). در مطالعه ديخر مشخص شد كه ميزان غفلت آموزشى در

تورنتوى كانادا نسبت به ساير كشورها كم بوده است ( (Y). با وجود اين كه مطالعات و بررسـى هاى بسـيارى به ارائه تعريف و مصـاديق سـوءرفتار و غفلت آموزشى اشاره داشتند، اما هنوز ابزارى براى سنجش اين دو سازه مهم ارائه نشده است.

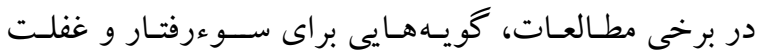

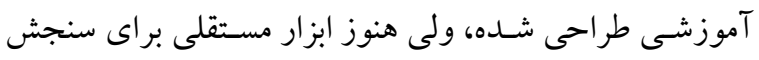

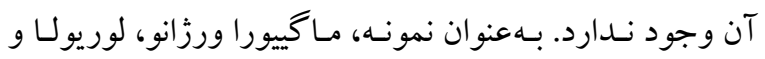

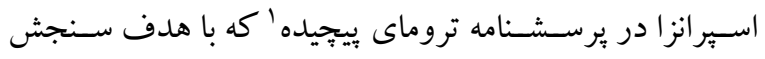
آسيب هاى ارتباطى اوليه كود كان طراحى شده بود به موضوع مهم غفلـت آموزشـى مانند كو تاهى در فراهم آوردن تعليم و تربيت مناسب و فرصت هاى ياد گيرى (ماند گويه: بدر و مادر به اينكه كودك از آموزش و يرورش مناسبى برخوردار شود،

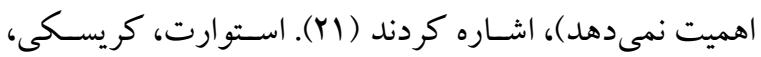
لانگك و جيانكولا در بزووهشى با هدف ساخت و رواسازى ابزار

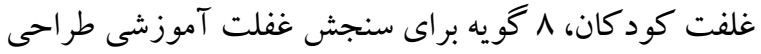

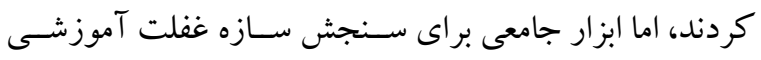

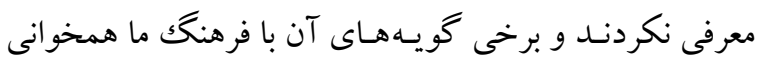
نداشته و مصاديق عينى ندارد (YY).

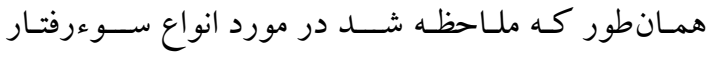
(جسـمانى، جنسى، عاطفى، و غفلت) هم اطلاعات كافى و هم يُزوهش هاى مطلوبى صسورت گَ فته و علاوه بر آن در ويرايش ينجم راهنماى تشـخيصسى و آمارى اختلالات روانى براى آن

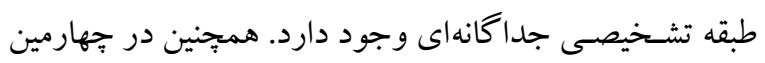

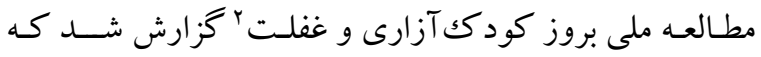
دربـاره كودكك آزارى و غفلت اطلاعات كافى وجود دارد، اما در زمينه سـوءرفتار آموزشى و غفلت آموزشى اطلاعات بسيار اندكى وجود دارد و بررسـى ها و مطالعات در آغاز راه اسـت.

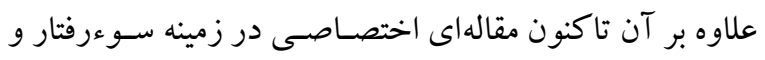
غفلت آموزشى به جاب نرسيده و تنها در مقالات اندكى به اين 
توسط حسين خانى و همكاران طراحى شد كه داراى צY گويه

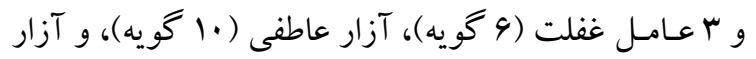

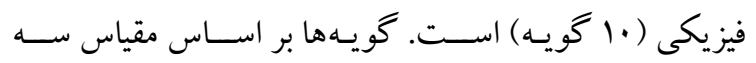
درجهاى ليكرت ( = هيج وقت، ب=كاهى اوقات و ب=هميشه)

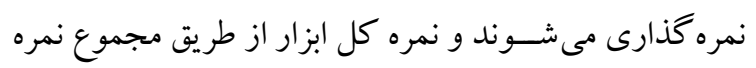

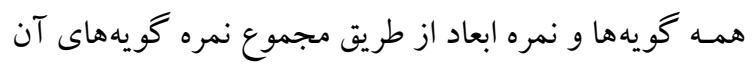

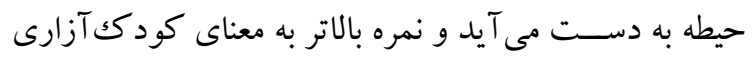

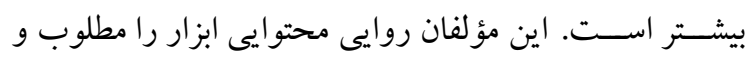

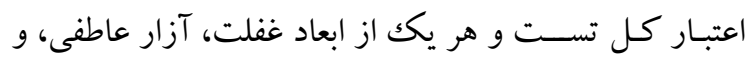

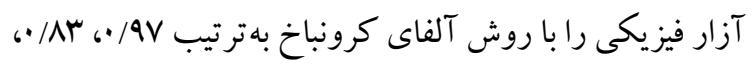

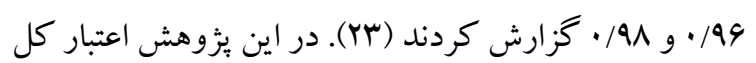
و هر يـك از حيطههـاى ابعـاد غفلـت، آزار عـاطفى، و آزار

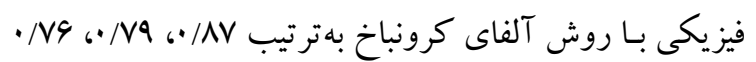
و • • • ب به دست آمد. ج) روش اجرا: براى انتخـاب نمونه از ميان همه دانش آموزان يايههاى جهارم تا ششم ابتدايى با مجوز ادارههاى ناحيه يكك و

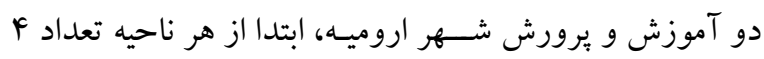

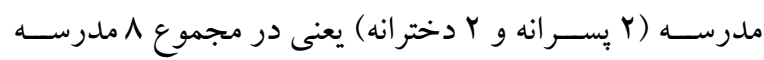
انتخاب شد و سبس از هر مدرسه ب كلاس در پايه هاى متفاوت

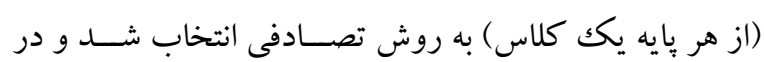

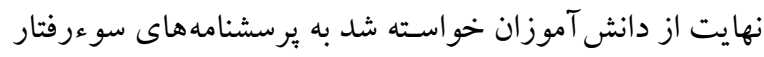
و غفلت آموزشى و كود كك آزارى بِاسـخ دهند. بِيش از ياسخ

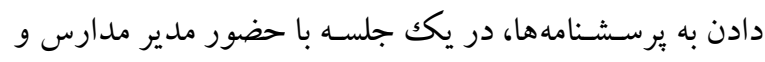

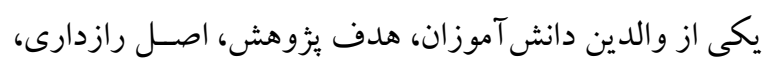

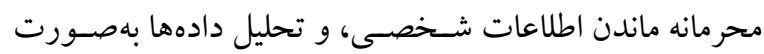
كلى براى آنان (دانش آموزان و يكى از اولياى آنها) بيان شد و

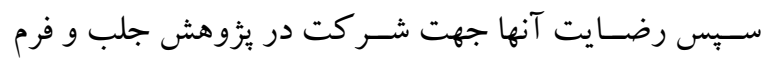
رضـايتنامه شركت آكاهانه در بزّوهش توسط آنان امضا شد.

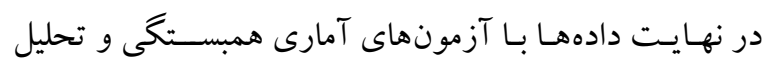

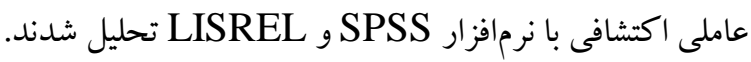

نزديكان در شش ماه گذشته، عدم امضاى رضايتنامه شر كت در بزؤهش، و تكميل برسشنامهها بهصورت ناقص بود.

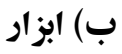
الف) بِرسـشـامه سـوءرفتار و غقلت آموزشسى: براى سـاخت

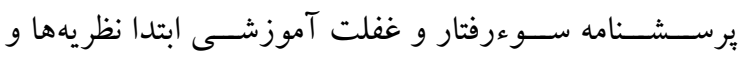

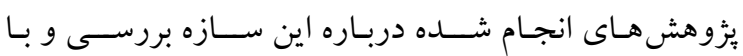
متخصصان روانشناسى و تعليم و تربيت در زمينه سوءرفتار و و

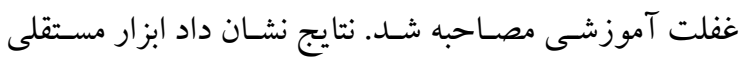

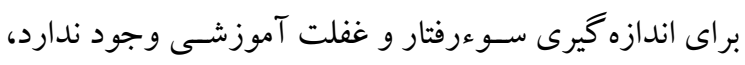

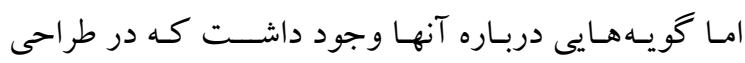

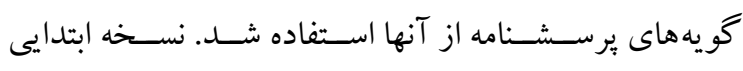

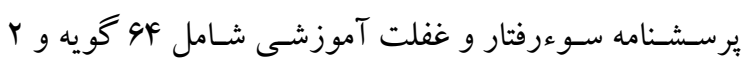

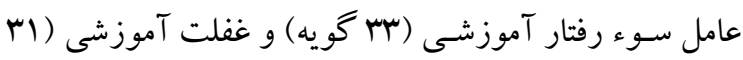

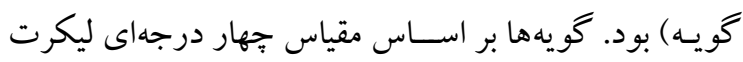

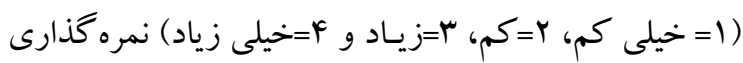

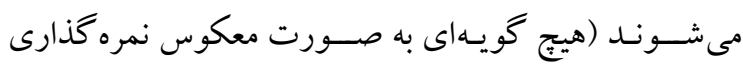

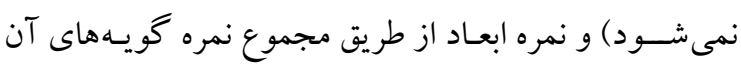

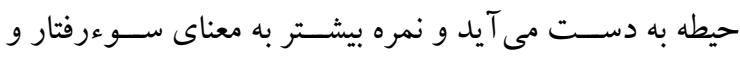

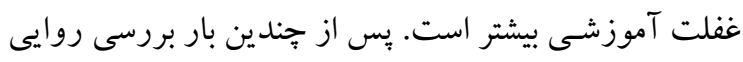

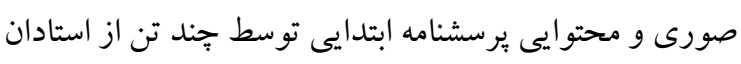

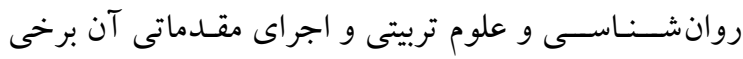

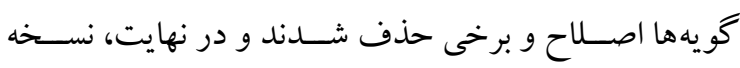

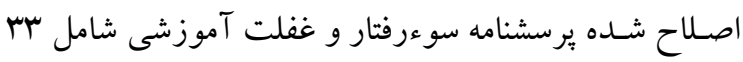

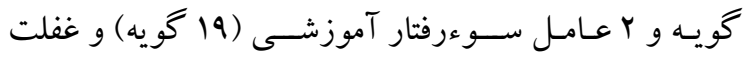

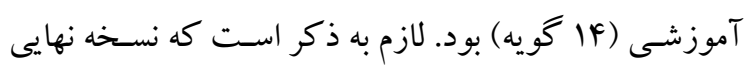

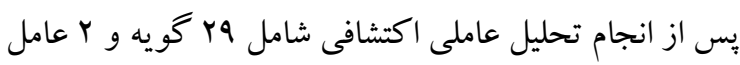

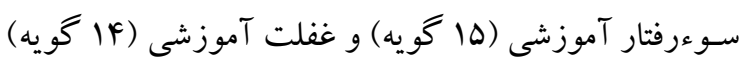
تدوين شد.

همجينين روايى همزمان برسـشــنامه سـوءرفتار آموزشسى و

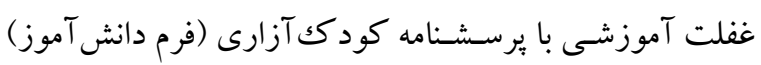
حسين خانى و همكاران (Tr) بررسى و تأييد شد.

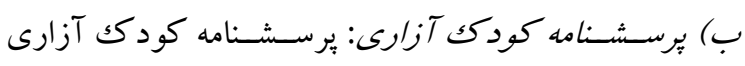


يافتهها

در جدول ا براى اطمينان از كفايت حجم نمونه و صـفر نبودن ماتريس همبستخى دادهها نتايج آزمونهاى بارتلت ارائه شد.

جدول ا: نتايج آزمون كفايت نمونه و صفر نبودن ماتريس همبستىى دادهها

\begin{tabular}{|c|c|c|c|c|c|}
\hline \multicolumn{3}{|c|}{ غفلت آموزشى } & \multicolumn{3}{|c|}{ سوءرفتار آموزشى } \\
\hline \multicolumn{2}{|c|}{ آزمون بارتلت } & \multirow[t]{2}{*}{ KMO } & \multicolumn{2}{|c|}{ آزمون بارتلت } & $\mathrm{KMO}$ \\
\hline سطح معنىدارى & مجذور خى & & سطح معنىدارى & مجذور خى & \\
\hline.$/ .1$ & $10 r \& / 9$ &.$/ 9 F$ &.$/ .1$ & $\mid F \Delta \Delta / Y$ &.$/ 9 r$ \\
\hline
\end{tabular}

جهـت تعيين تعـداد عامل هاى يرســشــنامه نتايج روش تحليل موازى ارائه شد.

\begin{tabular}{|c|c|c|c|c|}
\hline$\varepsilon$ & $r$ & $r$ & 1 & متغيرهاى يزوهش \\
\hline & & & 1 & ا. سوءرفتار آموزشى \\
\hline & & 1 & $\cdot / Y^{4^{\text {絭 }}}$ & r. غفلت آموزشى \\
\hline & 1 & $\cdot / \Upsilon \Lambda^{* * *}$ & $\cdot / \uparrow^{2}$ & r. سوءرفتار عاطفى \\
\hline 1 & $\cdot / A r^{* * * a}$ & $\cdot / \pi Y^{* * *}$ & $\cdot / 4 r^{*}$ & f. سوءرفتار فيزيكى \\
\hline 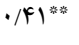 & $\cdot / \mathcal{G}^{* * * * * *}$ & $\cdot / A V^{* * *}$ & $\cdot / \& q^{*}$ & ه. سوءرفتار غفلت \\
\hline
\end{tabular}

$\mathrm{P}<\cdot / \cdot 1$
طبق نتايج جدول ا، مىتوان كفت كه اجراى تحليل عاملى قـابـل توجيه اســت. در جدول Y جهت بررسـى همبســـى متغيرهـاى يثزوهش و بررسـى بيش فرض عسدم وجود رابطـه همخطى جند گانه ميان عو امل نتايج ضرايب همبستگى ييرسون ارائه شد.

در جــدول Y، نتـايج همبســــى متغيرهـاى يثزوهش قـابـل مشـاهده اسـت. بر يايه ضـر ايب همبسـتخى به دسـت آمده كه همكى كمتر از هA/ • هستـند، فرض عدم وجود رابطه همخطى

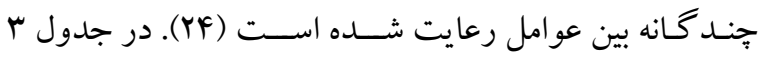
جدول rا: نتايج تحليل موازى

\begin{tabular}{|c|c|c|c|c|}
\hline & & & & سوءرفتار آموزشى \\
\hline واريانس تبيين شده & مقدار ويزه & ميانخين مقدار ويزههاى تصادفى & مقدار ويزه دادههاى واقعى & عامل \\
\hline \multirow[t]{3}{*}{$\cdot / 49$} & $9 / 94$ & $1 / 49$ & $9 / 94$ & 1 \\
\hline & & $1 / \pi V$ & $1 / 11$ & r \\
\hline & & & & غفلت آموزشى \\
\hline واريانس تبيين شده & مقدار ويزه & ميانخين مقدار ويزههاى تصادفى & مقدار ويزه دادههاى واقعى & عامل \\
\hline \multirow[t]{2}{*}{$\cdot / \Delta 1$} & $V / r$. & $1 / F V$ & $V / r$. & 1 \\
\hline & & $1 / \pi \Delta$ & $1 / r 1$ & r \\
\hline
\end{tabular}

جدول F جهت دسـيابى به سـاختار عاملى سـاده نتايج تحليل عاملى اكتشافى با روش جرخش متمايل عامل هاى بر امين ارائه

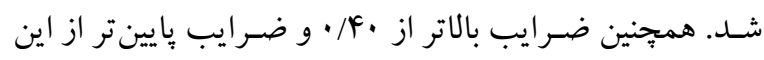

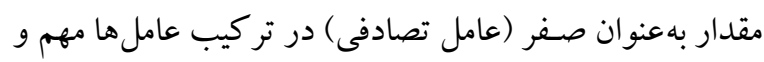
معنادار در نظر گرفته شد (Yo)
طبق نتسايج جدول r، مقدار ويزه عامل دوم در هر دو ابزار

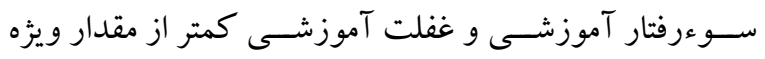
تصادفى است، بنابر اين روش تحليل موازى بيشنهاد مى كند كه

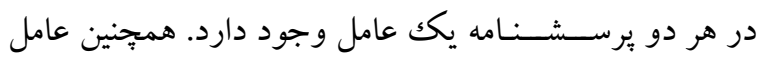

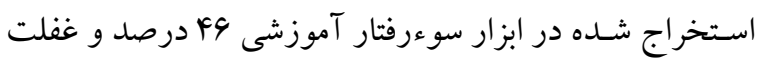

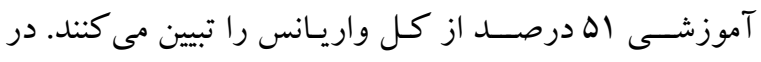


جدول ع: نتايج تحليل عاملى اكتشافى با روش جرخش متمايل عاملهاى برامين

\begin{tabular}{|c|c|c|c|c|c|}
\hline \multicolumn{3}{|c|}{ غفلت آموزشى } & \multicolumn{3}{|c|}{ سوءرفتار آموزشى } \\
\hline $\mathrm{R}^{2}$ & بار عاملى & كويهها & $\mathrm{R}^{2}$ & بار عاملى & كويهها \\
\hline$\cdot / Y \Lambda$ & ./ar & 1 & $\cdot / \Delta r$ & $\cdot / V r$ & 1 \\
\hline$\cdot / r$. & $\cdot / \Delta \Delta$ & r & r & $\cdot / \Delta V$ & r \\
\hline$\cdot / 49$ & $\cdot / \Delta F$ & $r$ & Y & $\cdot / \Delta V$ & $r$ \\
\hline$\cdot 109$ & - NQ & r & $\cdot / 4 \Lambda$ & $\cdot / v \cdot$ & f \\
\hline r l & $\cdot / 09$ & $\Delta$ & $\cdot / 49$ & $\cdot / 01$ & $\theta$ \\
\hline .190 & $\cdot / \Lambda 1$ & 4 & $\cdot / F F$ & .199 & 4 \\
\hline$\cdot / \mu$ & $\cdot 109$ & $\checkmark$ & $\cdot / 149$ &.$/ 01$ & V \\
\hline$\cdot / k r$ & .190 & $\wedge$ & .190 & $\cdot / 11$ & $\wedge$ \\
\hline .19 & $\cdot / \mathrm{VV}$ & 9 & $\cdot / Y \wedge$ & $\cdot / \Delta r$ & 9 \\
\hline$\cdot / \Delta F$ & $\cdot / \mathrm{r}$ & 1. & .19 & $\cdot / \mathrm{VA}$ & 1. \\
\hline .190 & $\cdot / 11$ & 11 & . $/ F r$ & .190 & 11 \\
\hline • & $\cdot 19$ & ir & .190 & $\cdot / 11$ & ir \\
\hline$\cdot / \Delta F$ & $\cdot / \mathrm{r}$ & ir & $\cdot / r \Delta$ & $\cdot / 0$ & ir \\
\hline \multirow[t]{2}{*}{.190} & $\cdot / 11$ & if & rr/. & $\cdot / \Delta \mathrm{V}$ & If \\
\hline & & & $\cdot / \mu F$ & $\cdot 109$ & 10 \\
\hline
\end{tabular}

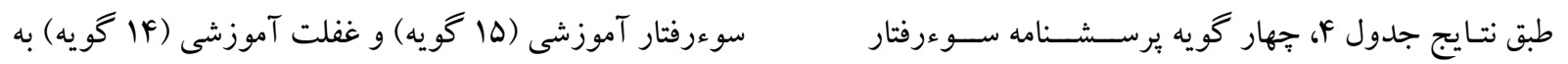

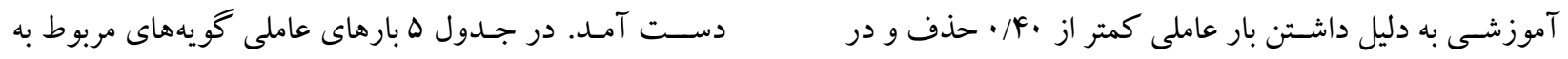

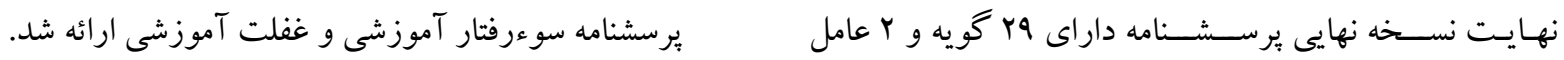

\begin{tabular}{|c|c|c|c|c|c|}
\hline \multicolumn{3}{|c|}{ غفلت آموزشى } & \multicolumn{3}{|c|}{ سوءرفتار آموزشى } \\
\hline $\mathrm{R}^{2}$ & بار عاملى & كويهها & $\mathrm{R}^{2}$ & بار عاملى & كويهها \\
\hline$\cdot / 4 \Lambda$ & $\cdot / \Delta r$ & 1 & $\cdot / \Delta r$ & $\cdot / N r$ & 1 \\
\hline$\cdot / r$. & $\cdot / \Delta \Delta$ & r & r & $\cdot / \Delta V$ & r \\
\hline$\cdot / r q$ & $\cdot / \Delta F$ & $r$ & $\cdot /$ Tr & $\cdot / \Delta V$ & $r$ \\
\hline .109 & $\cdot / v \Delta$ & f & $\cdot / F A$ & $\cdot / v$ & f \\
\hline 每 & .109 & $\Delta$ & $\cdot / 49$ & $\cdot / 01$ & $\Delta$ \\
\hline .190 & $\cdot|A|$ & 4 & $\cdot / F F$ & $\cdot 199$ & 9 \\
\hline ו ا & .109 & $\checkmark$ & $\cdot / 49$ &.$/ 01$ & $\checkmark$ \\
\hline$\cdot / 4 \mu$ & .190 & $\wedge$ & .190 & $\cdot / \wedge 1$ & $\wedge$ \\
\hline .19 & $\cdot / \mathrm{VV}$ & 9 & $\cdot /$ / & $\cdot / \Delta r$ & 9 \\
\hline$\cdot / \Delta F$ & $\cdot / N r$ & 1. &.$/ 9$ & $\cdot / \mathrm{VA}$ & 1. \\
\hline$\cdot 190$ & $\cdot|A|$ & 11 & $\cdot / F r$ & .190 & 11 \\
\hline . & $\cdot 19$ & ir & .190 & $\cdot / \wedge 1$ & ir \\
\hline$\cdot / \Delta F$ & $\cdot / N$ & ir & $\cdot / r \Delta$ & $\cdot / \Delta$ & ir \\
\hline \multirow[t]{2}{*}{.190} & $\cdot|A|$ & if & . & $\cdot / \Delta V$ & if \\
\hline & & & $\cdot / M F$ & .109 & 10 \\
\hline
\end{tabular}


مى دهــد و يـا بــدر و مـادرم انتظـار دارند كه به خو اهر و برادر

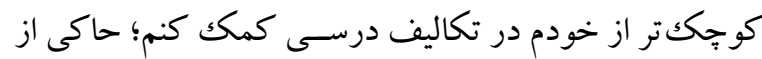
انتظار زياد والدين و معلمان از دانش آموزان است.

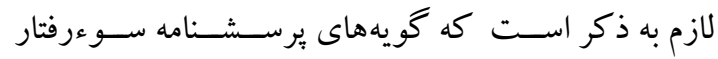
آموزشسى با بيشــينه نظرى و تجربى همسـو هســند. براى مثال

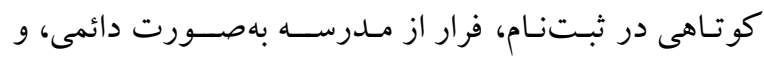

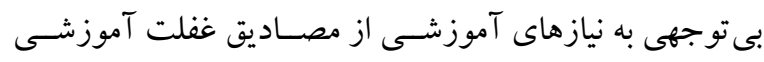

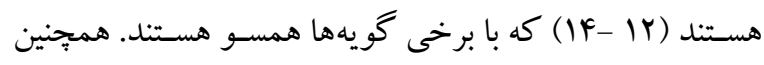

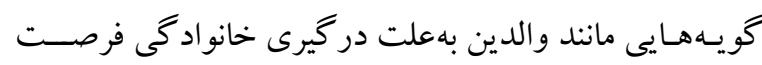
كافى براى رسيدگى به مسائل تحصيلى و آموزشى دانش آموز را ندارند؛ دانش آموز در ياد گيرى دجّار مشكل است و و الدين

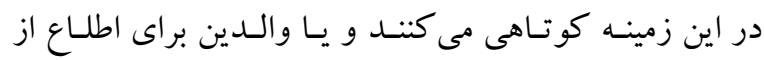

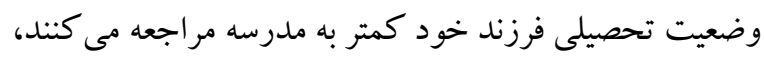

$$
\text { نيز در همين راستا است. }
$$

بررسى روايى سـازه ابزار نشـان داد گو يههاى برسـشـــامه

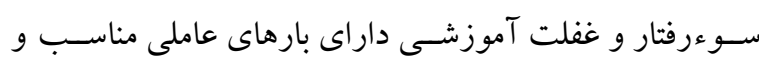
عامل هاى زيربنايى همســو با ســازههاى آن بودند. براى نمونه

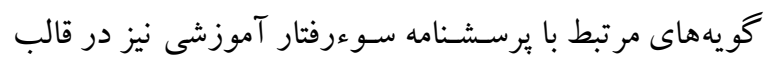

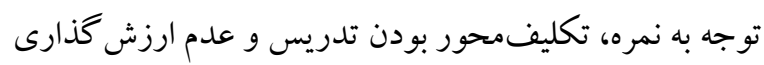

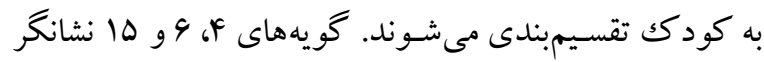

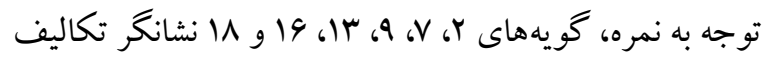

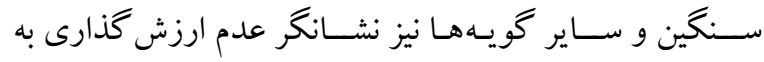

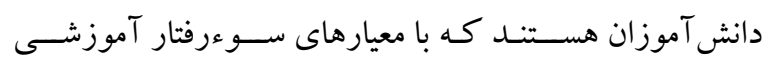
نيكسـون و فريمن (N) همخوان اسـت. علاوه بر آن كويههاى يرسشنامه غفلت آموزشى حاكى از كو تاهى والدين در فراهم آوردن نيازهاى آموزشى فرزندان و فراهم كردن شرايط تعليم و تربيت و ياد گيرى براى كود كان است.

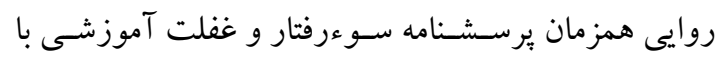

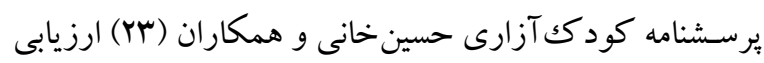
شـد كه نتايج حاكى از روايى همزمان برسـشنامه بود. اين يافته

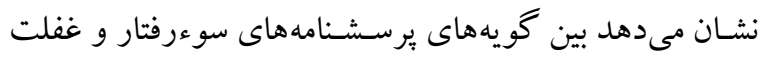

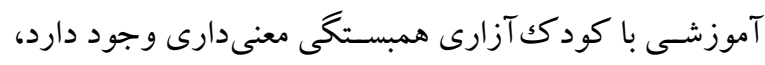

طبق نتـايج جدول ه، مقادير بارهاى عاملى گزارش شــده،

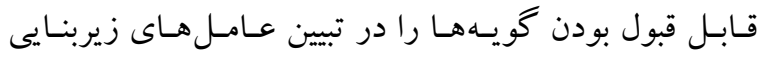

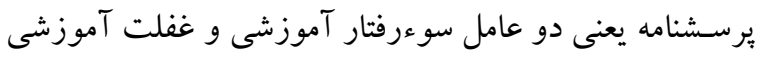

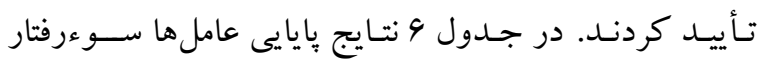
آموزشى و غفلت آموزشى با روش آلفاى كرونباخ ارائه شد.

\begin{tabular}{|c|c|}
\hline ش آلفاى كرونباخ & دول \: يايايیى = \\
\hline مقدار آلفاى كرونباخ & عامل ها \\
\hline$\cdot / 91$ & سوءرفتار آموزشى \\
\hline$\cdot / 94$ & غفلت آموزشى \\
\hline
\end{tabular}

بر اسـاس نتايج جدول 9، مقدار وِيايى عامل هاى سوءرفتار آموزشسى و غفلت آموزشسى با روش آلفاى كرونباخ بهترتيب

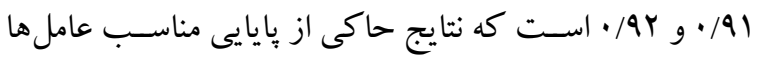

\section{بحث و نتيجل كيرى}

هدف يزوهش حاضر ساخت و رواسازى يرسشنامه سوءرفتار و

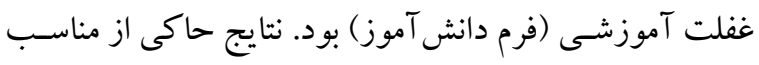
بودن روايى صسورى، محتو ايى، و همزمان و همجنين شـاخص

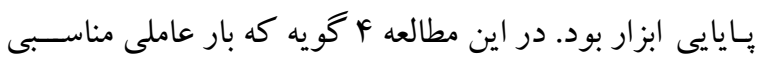

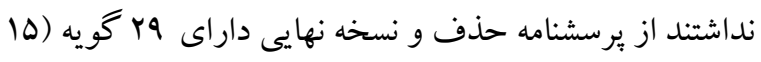

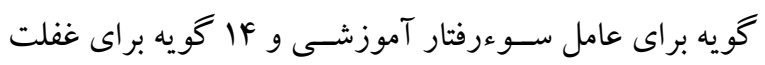
آموزشى) بود كه همه گويهها بار عاملى مناسبى داشتند.

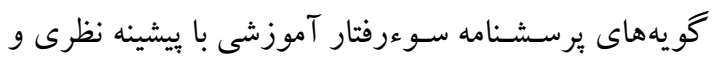

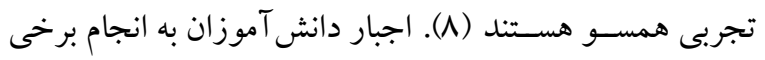

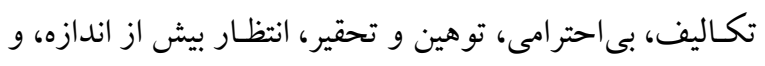

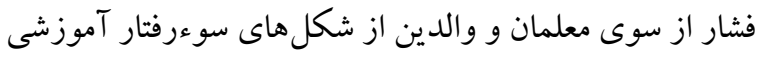

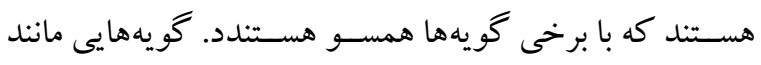

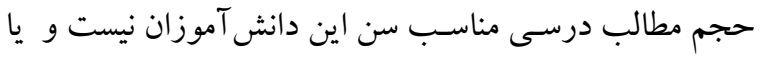

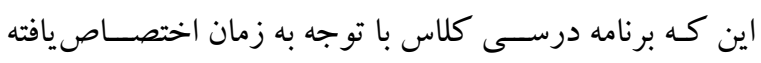

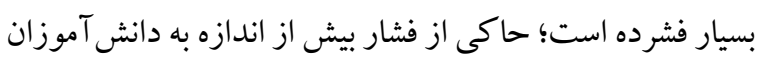

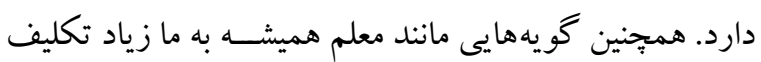


از كود كى، عاملى را بهعنوان غفلت آموزشى استخراج كردند؛ بنابر اين در حالت كلى مى توان بيان داشت كه گويهها و عوامل

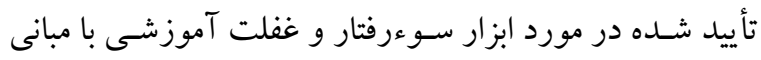
نظرى و تجربى مجود همسو هستند. در تبيين وجود جنين سازه

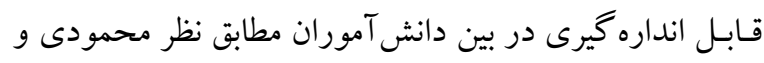
همكاران (ه) (1)، كم توجهى به نيازهاى روانى اسـاسى، امكانات

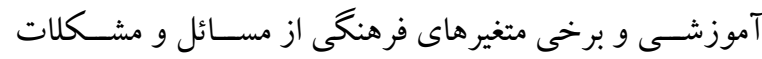

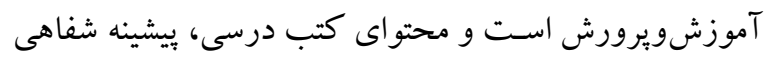

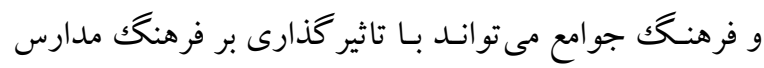

$$
\text { موجب بروز سوءرفتار و غفلت آموزشى شود (F). }
$$

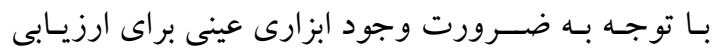

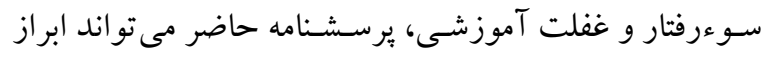

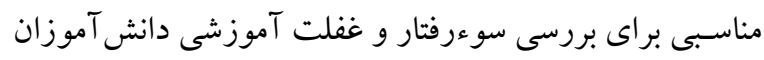

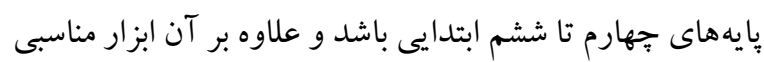

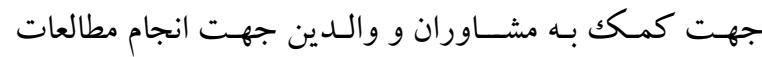
تشـخصى و يثزوهشى باشد؛ در نتيجه لازم است تا متخصصان تعليم و تربيت بر اسـاس مطالعات ميدانى به بررسسى وضسعيت

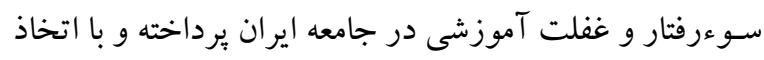

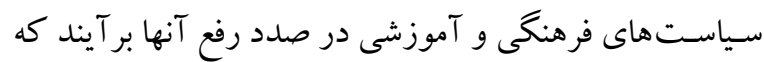
در اين زمينه يرســــامه سـوءرفتار و غفلت آموزشى مي توتواند مقدمات دست يابى به اين هدف را فراهم آورد. فرم دانش آموز

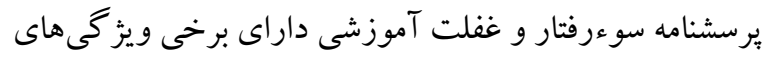
ممتاز است كه مى تواند راهخشاى شناسايى و حل برخى مسائل

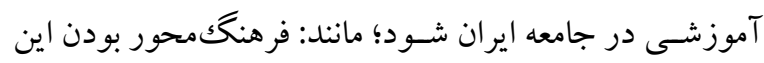

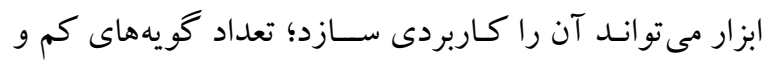
روشـن اين ابزار باعث مى شـود كه بتوان از آن در تمام مقاطع

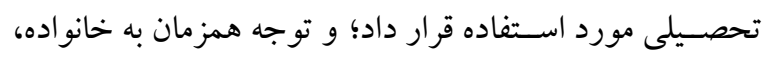
مــدرســه، معلم، و جـامعـه در اين ابزار كـه مى تو انـــ مســائل

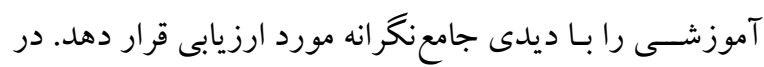
نتيجه يرسـشنامه سوءرفتار و غفلت آموزشى مى تواند مقدمهاى براى انجـام تحقيقات در حوزه مســائل مرتبط با ســوءرفتار و و
براى نمونه گ گيه \از سـو عرفتار آموزشـى (يعنى وقتى من در باسخ به درس موفق نيستم، معلمم مرا تحقير مى كند) با بسيارى از گويههاى كودككآزارى از جمله سؤال ال (يعنى آيا در خانه

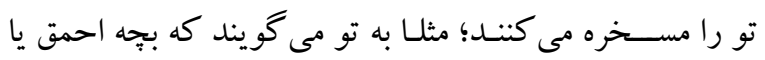
بع عرضـهاى هستى؟؟)، از لحاظ مفهومى بسيار نزديكك هستند.

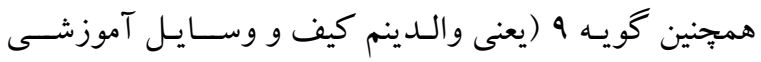

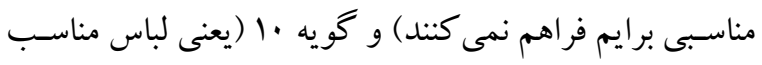

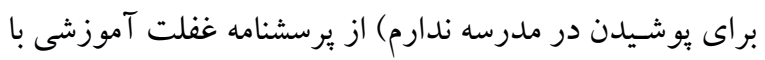

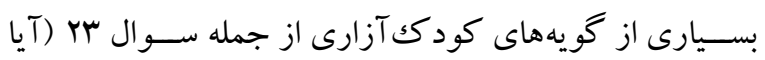
لباسها و كفش هاى كهنه و كثيفى را كه مى يوشـى دوســت دارى؟) و سـوال FF (آيا در خانه كتاب و لوازم مدرسـهـ مثل مــاد، دفتر، خودكـار و ... را كـه تو احتيـاج دارى برايست مىخرند؟)، داراى اشتراكك مفهومى است. مطالب ذكر شده بر مبناى نظر ديوب و مككجيبونى منطقى به نظر مىرسـد، زيرا از

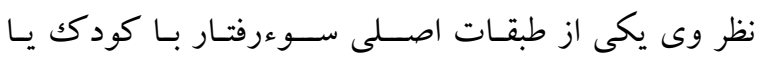
كود كك آزارى، سـوءرفتار آموزشى يا غفلت آموزشى اسـت

بهور كلى گويههاى برسـشــنامه ســوءرفتار آموزشسى و

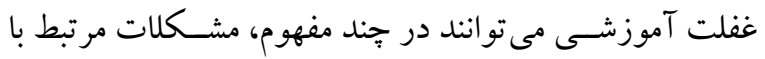

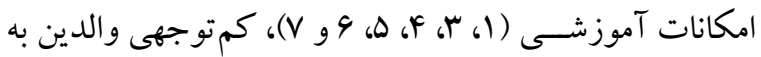

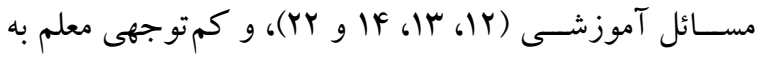
مسائل آموزشى (Tr M و (YF) را نشان دهند. علاوه بر آن كويهها منطبق بـا مبـانى نظرى و تجربى در زمينه ســـ عرفتـار و غفلت آموزشـى هســتنـد. براى مثـال آجـاكك و همكـاران (IF)

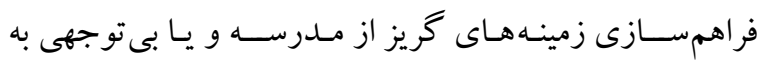
نيازهاى آموزشـى را از نشــانههاى غفلت آموزشـى مى مداند.

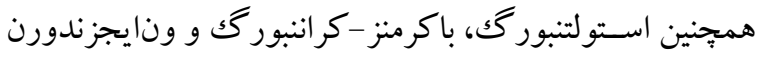

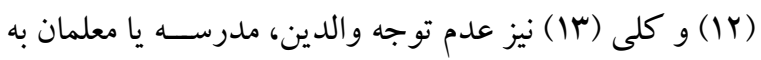
نيازهاى آموزشى (امكانات مرتبط با آموزش و توجه به فرايند ياد كيرى دانش آموزان) را از مشـخصه هاى مرتبط با سو عرفتار

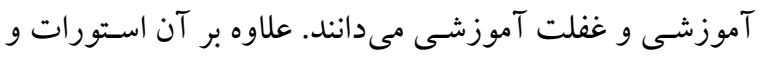
همكاران (Yr) نيز در مطالعهاى با هدف رواســازى ابزار غلفت 
اين گزارشـات از طريق مصــاحبـه و ارزيابى هاى محدود از وضـعيت مدارس حاصـل شـده است. يكى از كاربردهاى ابزار حاضـر بررسى شيوع شـناسى سوءرفتار و غفلت آموزشى در

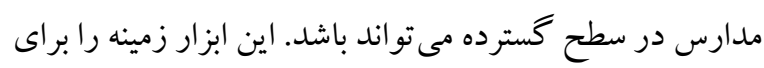

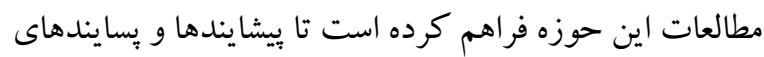
مر تبط با سـو عرفتار و غفلت آموزشسى مورد مطالعه قرار گيرد. همجينين اين ابزار مى تو اند در زمينه هاى آموزشى و بالينى مورد

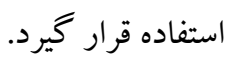

تشـكر و قدردانى: اين يثزوهش بر كرفته از پايان نامه كارشـناسى

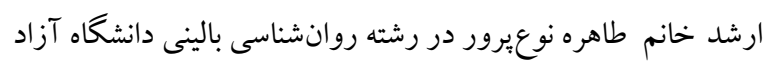

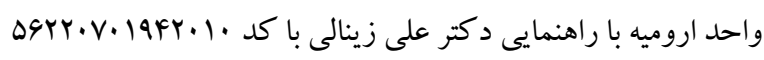

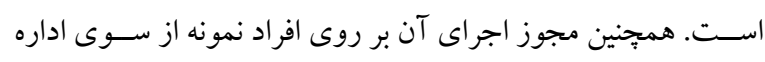

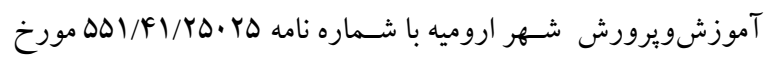

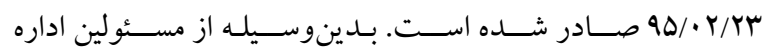

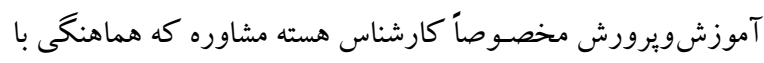

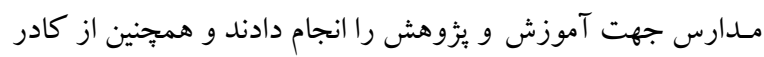

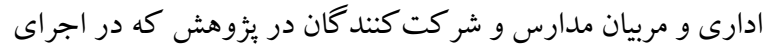
اين طرح به ما كمكك كردند، تشكر و قدردانى مى مشود. تضــاد منافع: در اين مقاله هيج تعارض منافعى براى نويســندان

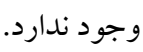

غفلت آموزشى در بين دانش آموزان ايرانى باشد و يثزوهشخران مى تواند از اين ابزار در مطالعات خود بهرهمند شوند. يزووهش حساضـر با محدوديت هايى نيز مواجه بود. جديد بودن موضسوع و بيشـينه نظرى و تجربى محدود براى سـاخت

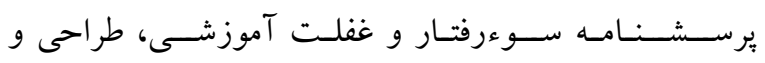

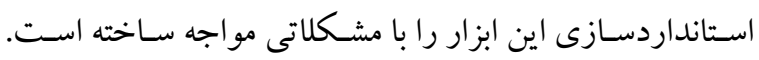
نمونه مورد مطالعه به دانش آموزان يايههاى جهارم تا ششم شهر

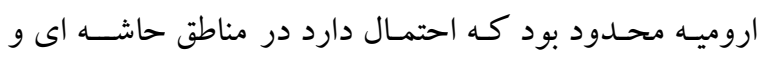
روسـتاها، سـو رفتار و غفلت آموزشسى با شـدت بيشترى تاييد

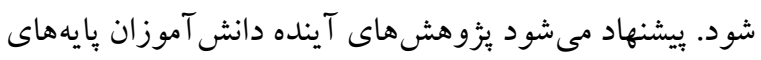

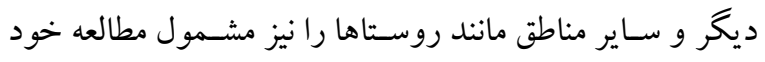

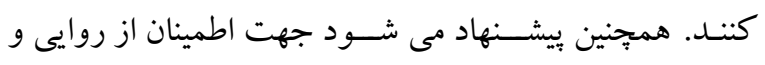

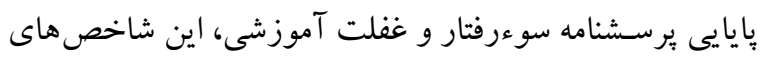
روانسنجى در مطالعات ديخر نيز بررسى شود تادقت و اعتبار

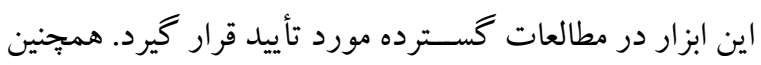
لازم به ذكر اسـت كه در اين ئزوهش فرم دانش آموز ســاخته شــده و شـاخص هاى روانســنجى آن بررسـى شـــ، بنابراين بيشــنهاد مى شـود در يزوهشهاى آتى، نسخه معلمان يا والدين

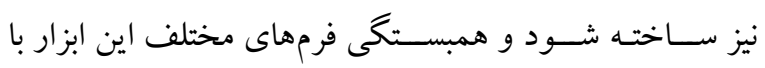
يكديخر محاسبه و بررسى شود. در هر صسورت مطالعات انجام شـده شسيوع نسبتاً بالايى را براى سوءرفتار و غفلت آموزشى گزارش كردند (1) IV (19). 


\section{References}

1. Sedlak AJ, Mettenburg J, Basena M, Peta I, McPherson K, Green A, et al. Fourth national incidence study of child abuse and neglect (NIS-4). Washington, DC: US Department of Health and Human Services; 2010, pp: 1-3. [Link]

2. Khanjari S, Bastani F, Kamalinahad R, Hosseini A. Prevention of child sexual abuse: Parents' knowledge, attitudes and practices. Iran Journal of Nursing. 2014; 27(89): 12-20. [Persian]. [Link]

3. American Psychiatric Association. Diagnostic and statistical manual of mental disorders (DSM-5®). American Psychiatric Pub; 2013. [Link]

4. Dube SR, McGiboney GW. Education and learning in the context of childhood abuse, neglect and related stressor: The nexus of health and education. Child Abuse Negl. 2018; 75: 1-5. [Link]

5. Isangedighi AJ, Ajake UE, Bisong NN. Child abuse and emotional stability among senior secondary school students in Cross River State, Nigeria. Lwati: A Journal of Contemporary Research. 2009; 6(1): 17-25. [Link]

6. Uchenna A, Ukpong EM, Jamabo A. Sexual abuse and self-concept among senior secondary school students in Cross-River State, Nigeria. Annals of modern Education. 2011; 3(1): 10-19. [Link]

7. Balkaran S. Impact of child abuse education on parent's self-efficacy: An experimental study [Ph.D. Thesis]. [Minnesota, USA]: College of Social and Behavioral Sciences, Walden University; 2015, pp: 3-7. [Link]

8. Nixon JW, Freeman AO. Guidelines for mandated reporters of child abuse and neglect. Missouri Department of Social Services, Children's Division, 2018, pp: 5-18. [Link]

9. Malimabe-Ramagoshi RM, Maree JG, Alexander D, Molepo MM. Child abuse in Setswana folktales. Early Child Dev Care. 2007; 177(4): 433-448. [Link]

10. Manly JT, Oshri A, Lynch M, Herzog M, Wortel S. Child neglect and the development of externalizing behavior problems: associations with maternal drug dependence and neighborhood crime. Child Maltreat. 2013; 18(1): 17-29. [Link]

11. Scott D. Understanding child neglect (CFCA Paper No. 20). Child Family Community Australia, Melbourne: Australian Institute of Family Studies; 2014, pp: 1-17. [Link]

12. Stoltenborgh M, Bakermans-Kranenburg MJ, van IJzendoorn MH. The neglect of child neglect: a metaanalytic review of the prevalence of neglect. Soc Psychiatry Psychiatr Epidemiol. 2013; 48(3): 345-355. [Link]

13. Kelly P. Where are the children? Educational neglect across the fifty states. The Researcher. 2010; 23(1): 41-58. [Link]

14. Ajake UE, Oden SN, Bisong NN. Influence of child neglect on self-concept of senior secondary school students in Cross River State, Nigeria. Journal of Educational and Social Research. 2014; 4(3): 239244. [Link]

15. Mahmoudi H, Brown MR, Amani Saribagloo J, Dadashzadeh S. The role of school culture and basic psychological needs on Iranian adolescents' academic alienation: A multi-level examination. Youth Soc. 2018; 50(1): 116-136. [Link]

16. Chapple CL, Vaske J. Child neglect, social context, and educational outcomes: Examining the moderating effects of school and neighborhood context. Violence Vict. 2010; 25(4): 470-485. [Link]

17. Euser S, Alink LRA, Pannebakker F, Vogels T, Bakermans-Kranenburg MJ, Van IJzendoorn MH. The prevalence of child maltreatment in the Netherlands across a 5-year period. Child Abuse Negl. 2013; 37(10): 841-851. [Link]

18. Browne K, Cartana C, Momeu L, Paunescu G, Petre N, Tokay R. National prevalence study of child abuse and neglect in Romanian families. Copenhagen: WHO Regional Office for Europe; 2002, pp: 115.

19. Vasa AAK, Sahana S, Sekhar KR, Rajaram B, Pusphalatha, Vemulapalli S. Dental graduates awareness of child abuse and neglect (CAN). Br J Med Med Res. 2015; 9(5): 1-7. [Link]

20. Van Wert M, Fallon B, Trocme N, Collin-Vézina D. Educational neglect: understanding 20 years of child welfare trends. Child Abuse Negl. 2018; 75: 50-60. [Link] 
21. Maggiora Vergano C, Lauriola M, Speranza AM. The complex trauma questionnaire (complextq): development and preliminary psychometric properties of an instrument for measuring early relational trauma. Front Psychol. 2015; 6: 1323. [Link]

22. Stewart C, Kirisci L, Long AL, Giancola PR. Development and psychometric evaluation of the child neglect questionnaire. J Interpers Violence. 2015; 30(19): 3343-3366. [Link]

23. Hosseinkhani Z, Nedjat S, Majdzadeh R, Mahram M, Aflatooni A. Design of the child abuse questionnaire in Iran. Journal of School of Public Health and Institute of Public Health Research. 2014; 11(3): 29-38. [Persian]. [Link]

24. Tabachnick BG, Fidell LS. Using multivariate statistics, 5th ed. Boston, MA: Allyn \& Bacon/Pearson Education; 2007, pp: 58-89. [Link]

25. Kline RB. Principles and practice of structural equation modeling, 4th ed. New York, NY, US: Guilford Press; 2016, pp: 188-209. [Link] 